\title{
Abiotic gradients drive floristic composition and structure of plant communities in the Monte Desert
}

\author{
Gradientes abióticos dirigen la composición florística y la estructura de las comunidades \\ de plantas en el Desierto del Monte
}

\author{
PABLO ACEBES ${ }^{1,}$ * JUAN TRABA $^{1}$, BEGOÑA PECO ${ }^{1}$, MARÍA L. REUS ${ }^{2,3}$, STELLA M. GIANNONI ${ }^{2,3} \& \mathrm{JUAN}^{2}$. \\ MALO $^{1}$ \\ ${ }^{1}$ Terrestrial Ecology Group, Departamento de Ecología, Darwin, 2, Universidad Autónoma de Madrid, E-28049 \\ Madrid, Spain \\ ${ }^{2}$ Instituto y Museo de Ciencias Naturales, España, 400 (N), 5400 Universidad Nacional de San Juan), Argentina \\ ${ }^{3}$ CONICET, Argentina \\ * Corresponding author: pablo.acebes@uam.es
}

\begin{abstract}
Defining plant communities in desert zones is difficult due to large scale homogeneity and small scale heterogeneity, thus making provision of systematic information for conservation decisions problematic. We analysed plant communities of the most arid sector of Monte Desert for structure, plant composition and environmental variables. Small-scale variables such as slope, rock cover, bare ground and litter, as well as largescale ones such as species diversity, composition and similarity within and between sites were included. Analyses of floristic composition showed the difficulty of segregating distinct communities due to high internal heterogeneity and overlap between the different sites. Only mesquite woodlands, a community situated at the extreme of the soil moisture-gradient was segregated. Ordination on structural variables was somewhat more successful in segregating communities on the basis of substrate type and of tree and shrub cover. Our results showed the difficulty distinguishing plant communities in temperate deserts, suggesting the existence of relatively stable assemblages of species at the extremes of the gradients and of great heterogeneity within and between sites. They cannot be defined by floristic variables solely, but require environmental information also.
\end{abstract}

Key words: arid environment, heterogeneity, shrubland, similarity, species richness.

\section{RESUMEN}

La definición de comunidades discretas de plantas en zonas desérticas es complejo debido tanto a su homogeneidad a gran escala como a su heterogeneidad a pequeña escala, lo que acaba generando dificultades para la toma de decisiones de conservación. En este trabajo analizamos las comunidades de plantas del sector más árido del Desierto del Monte en función de su estructura y composición florística. Se han utilizado también variables ambientales estimadas a pequeña escala como la pendiente o la superficie de roca, suelo desnudo y hojarasca, así como variables que operan a mayor escala como la diversidad de especies, la composición florística y la similitud dentro y entre localidades. Los análisis de composición florística resaltaron la dificultad para segregar diferentes comunidades debido al elevado nivel de heterogeneidad interna y de solapamiento florístico entre las distintas localidades estudiadas. Solo la comunidad situada en el extremo del gradiente de humedad edáfica, el algarrobal, se segregó del resto. La ordenación realizada sobre las variables estructurales en función del tipo de sustrato y de la cobertura arbórea y de matorral segregó mejor las diferentes comunidades. Nuestros resultados muestran la dificultad para diferenciar comunidades de plantas en desiertos templados, sugiriendo la existencia de ensamblajes de especies relativamente estables en los extremos de los gradientes y de una gran heterogeneidad dentro y entre localidades. Las comunidades de plantas, por tanto, no pueden ser definidas únicamente por variables florísticas, sino que es preciso incluir información ambiental.

Palabras clave: Arbustal, heterogeneidad, medio ambiente árido, riqueza de especies, similitud.

\section{INTRODUCTION}

Desert vegetation is relatively homogeneous on a large scale, but heterogeneous on a small scale, which makes it difficult for definition of plant communities for descriptive, scientific and practical purposes. Plant cover in ecosystems which are strongly water-limited is patchy and normally below $60 \%$ (Aguiar \& Sala 1999). Thus the presence of surface or subterranean water plays a fundamental role in plant communities distribution (Jobbágy et al. 
1996, León de la Luz et al. 2000, Zhang et al. 2005). Deserts have been defined as watercontrolled ecosystems with infrequent, discrete and largely unpredictible water inputs (Noy-Meir 1973). Large spatial heterogeneity occurs and vegetation is not uniform on a small scale (Xu et al. 2006) but rather clumped where environmental conditions are more severe (Tirado \& Pugnaire 2003). As a result, plant communities are structured around gradients of plant cover such that often they cannot be defined solely by floristic variables but require inclusion of environmental ones such as geomorphological and edaphic factors (Abd El-Ghani \& Amer 2003, Bisigato et al. 2009).

The Monte Desert biome characterizes the arid fringe of western Argentina, from $24^{\circ} 35^{\prime} \mathrm{S}$ in Salta province to $44^{\circ} 20^{\prime} \mathrm{S}$ in central Patagonia, and from $62^{\circ} 54^{\prime} \mathrm{W}$ on the Atlantic coast to $69^{\circ} 50^{\prime} \mathrm{W}$ in the pre-Andean zone (Morello 1958). It represents one of the most interesting South American biomes due to its high plants and mammals endemicity. A few plant genera show a remarkable phylogenetic similarity with taxa of North American deserts (Mojave and Sonora), but most plant species are closely related to those in Chaco and Patagonian biomes, and some authors consider the Monte Desert as a part of the South American Transition Zone (Roig et al. 2009).

Most studies within the Monte Desert have been carried out in regions where climatological conditions are not as severe as in its hyper-arid region. These include studies of seed banks (López de Casenave et al. 1998, Marone et al. 2000), to certain woody species such as Larrea spp. (Rossi et al. 1999), Prosopis spp. (Rossi \& Villagra 2003, Villagra \& Cavagnaro 2006, Campos et al. 2007) and Bulnesia retamo (Griseb) (Debandi et al. 2002) and plant/animal interactions (see review Bertiller et al. 2009). Studies of plant communities of the hype-arid Monte Desert are sparse and limited either to floral listings (Dalmasso \& Márquez 1999) or to phytosociological studies (Márquez et al. 2005). As a result necessary information for adequate protection is insufficient and of concern since drylands constitute vulnerable ecosystems facing strong global change (Millennium Ecosystem Assessment 2005). Less than $4 \%$ of the Monte Desert is protected, significantly lower than the proposed $10 \%$ for each eco-region by 2010 in "2010 - The Global Biodiversity Challenge" (Pol et al. 2006).

The present study reports on systematic analyses of the vegetation of a poorly known hyper-arid sector of the Monte Desert biome in order to determine whether plant communities can be identified there. We analyse vegetation units which differ in appearance (physiognomy) for floristic characters, and both structural and environmental variables, and compare patterns of diversity and similarity within and between communities.

\section{METHODS}

\section{Study area}

The work was conducted in the Ischigualasto Provincial Park $\left(29^{\circ} 55^{\prime} \mathrm{S}, 68^{\circ} 05^{\prime} \mathrm{O}\right)$, in San Juan province, Argentina, a World Heritage Site together with the adjacent Talampaya National Park (2000) in La Rioja province (Fig. 1). The park is over 60369 ha and has a mean altitude of $1300 \mathrm{~m}$ above sea level. The climate is as defined by W. Köeppen (Poblete \& Minetti 1999) desert, with mean annual temperatures below $18{ }^{\circ} \mathrm{C}$, a temperature range of $-10-45{ }^{\circ} \mathrm{C}$, and mean annual precipitation of $80-140 \mathrm{~mm}$ : occurring mainly in summer (November to February). Particularly, when the study was carried out (March 2005) the hydrologic year was rather dry and hot (data not published). Triassic sandstones dominate the soils of the zone with variable salt content, and in some cases, interspersed coal deposits. Fine-textured silts and Quaternary sediments also occur, forming pebbly expanses of a diverse nature.

\section{Data collection}

In order to maximise differences between the plant communities analysed six sites were selected. Two were defined on the basis of physiognomic characteristics: 1) columnar cactus slopes, dominated by Trichocereus terscheckii (Parm. Ex Pfeiff); and 2) barrens: mostly plantless zones. The other four were defined as a function of the apparently most abundant species: 3) saltbush: Atriplex spegazzinii (Soriano ex Mulgura); 4) creosote bush scrub: Larrea cuneifolia (Cav.); 5) mesquite woodlands: Prosopis chilensis (Stuntz); and 6) chical: Ramorinoa girolae (Speg.), a woody legume tree (Fabaceae) with almost leafless green stems. With respect to substrates, barrens, saltbush and mesquite woodlands are on fine sandysilty soils, the columnar cactus and chical are on rocky, principally sandstones slopes and creosote bush scrub is on consolidated Quaternary deposits. Moreover, these sites are on a gradient of water availability, from mesquite woodlands located along ephemeral watercourses to barrens, the driest zone of the Monte Desert.

Within these sites 20 sampling plots ( $\mathrm{n}=120$ plots) were selected at random were separated by at least 30 
m. At each sampling plot $132 \times 2 \mathrm{~m}$ subplots were established along two perpendicular lines, the first at their intersection and the remainder at $2 \mathrm{~m}$ intervals totalling $52 \mathrm{~m}^{2}$ sampling area per plot. The total sampling area was about 15 ha at each site with the exception of mesquite woodlands owing to its linear and discontinuous distribution along some of the dry watercourses.

In each subplot we estimated the following physiognomic variables: total plant cover at three strata ( $0.5 \mathrm{~m}, 1 \mathrm{~m}$ and canopy), rock cover, bare ground and litter cover; cover was assigned to the following categories (< $5 \%$; 5-10\%; 11-25\%; 25-50\%; 50-75\%; > 75 $\%)$. For floristic composition, the cover of each of the plant species was also estimated in each subplot (\%).

Sampling was designed with the aim to: (i) obtain robust estimates of plant composition in plots; and (ii) avoid inflated variation of plant composition in them. Thus, 13 subplots were sampled instead of a larger contiguous unit in order to minimize sampling variance produced by plant aggregation in patches, and the 22 m subplot size was selected after measuring average shrub dimensions in the area $(238 \pm 13 \times 215 \pm 13 \mathrm{~cm}$, mean $\pm \mathrm{SE}, \mathrm{N}=120$ ). Afterwards, a cumulative species analysis allowed us to estimate plant richness in 13 subplots $\left(52 \mathrm{~m}^{2}\right)$ in order to obtain $80 \%$ species richness expected had we sampled $100 \mathrm{~m}^{2}$ (25 subplots).

\section{Data analysis}

We used the midpoint of the cover class (i.e. $2.5 \%$; 7.5 $\%$; $18 \%$; $37.5 \%$; $62.5 \%$; $87.5 \%)$ to calculate the mean value and coefficient of variation for each variable at each sample point (plot), except for slope and altitude, which were recorded only at one point per plot, since they did not differ appreciably among the 13 sampling subplots (Table 1). Species richness was taken as the total number of species per sampling plot and per site. Within-site heterogeneity was calculated using Jaccard's qualitative index for similarity between sampling plots at a given site and overall between sites.

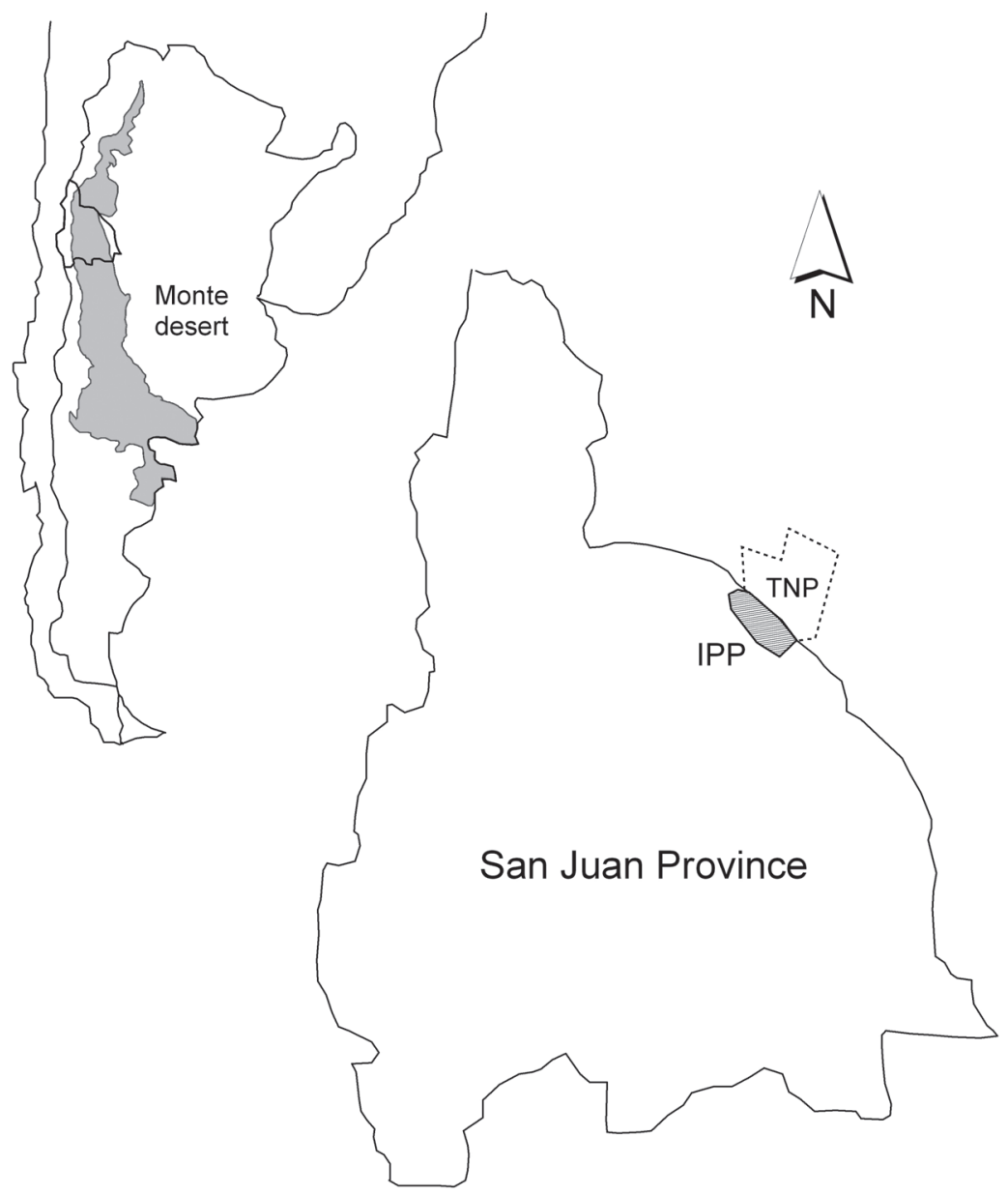

Fig. 1: Location of Ischigualasto Provincial Park (IPP) and Talampaya National Park (TNP) in San Juan and La Rioja provinces, repectively (Argentina). Distribution of the Monte Desert biome.

Localización del Parque Provincial Ischigualasto (IPP) y del Parque Nacional Talampaya (TNP) en las provincias de San Juan y la Rioja respectivamente (Argentina). Distribución del bioma Desierto del Monte. 
Principal Component Analyses (PCAs) were carried out on environmental and structural variables and on floristic composition to obtain components (axes) enabling simple interpretation and avoiding the problems of colinearity detected among the original variables in an initial exploratory analysis. For floristic composition the covariance matrix based on meancentered variables was chosen. It is appropriate when variables are measured in comparable units and differences in variance between them makes an important contribution to interpretation. For environmental and structural variables the correlation matrix based on variables standardized to zero mean and unit variance was chosen. It is necessary when variables are measured in very different units and differences between variances are ignored, i.e., slope, altitude, and plant, rock or litter cover (Quinn \& Keough 2002).

The PCA results for the differences in environmental and structural variables on the one hand, and those relating to floristic composition on the other, were analysed by means of multivariate analyses of variance (MANOVAs) in which the positions obtained via PCAs were used as dependent variables and sites as the predictive variable. Tukey's honestly significant difference test (HSD test) was used a posteriori to compare pairs of means. We selected this analytic approach to strengthen the differences in both floristic and environmental-structural variables among sites.

To determine significant differences in plant species among sites, Kruskal-Wallis tests of one factor (site) were carried out for each species, using mean plant cover per sampling plot as the dependent variable. False Discovery Rate (FDR) correction was employed to control alpha-inflation (García 2004). ANOVA test was used to compare total species richness per sampling plot between sites. Tukey's honestly significant difference test (HSD test) was used a posteriori to compare pairs of means. All analyses were carried out with STATISTICA 8.0 (StatSoft Inc. 2007)

\section{RESULTS}

Total species richness for the sampled sites was 69. The most abundant species, according to their frequency of occurrence in the six sites, were L. cuneifolia, A. spegazzinii, Zuccagnia punctata (Cav.), Prosopis torquata (Cav. ex Lag.) and $B$. retamo (see Appendix). The families represented by most species were the Cactaceae (12), Fabaceae (10), Solanaceae (7) and Poaceae (7). With respect to total cover, the families with the greatest cover were the Zygophyllaceae, Fabaceae, Chenopodiaceae and Cactaceae. Finally, including frequency of occurrence, the Bromeliaceae, with both terrestrial and epiphytic species, must be added to the last four families.

\section{TABLE 1}

Variables and their values recorded in the $2 \times 2$ m sampling subplots $(n=1560)$. Each site had 20 sampling plots. The altitude and slope variables were taken at the centre of each sampling plot (n = 120). Barrens (B), saltbush (S), creosote bush scrub (CB), mesquite woodlands (M), columnar cactus slopes $(\mathrm{CS})$ and Chical $(\mathrm{CH})$.

Variables y sus valores registrados en las subparcelas de $2 \times 2 \mathrm{~m}(\mathrm{n}=1560)$. Cada sitio tenía 20 parcelas de muestreo. La altitud y la pendiente fueron registradas en el punto central de cada parcela $(n=120)$. Peladal $(B)$, zampal (S), jarillal (CB) algarrobal (M), laderas con cactus columnares (CS) y Chical (CH).

\begin{tabular}{|c|c|c|c|c|c|c|c|c|}
\hline Variable & Code & B & $\mathrm{S}$ & $\mathrm{CB}$ & M & $\mathrm{CS}$ & $\mathrm{CH}$ & \\
\hline \multicolumn{9}{|l|}{ Environmental variables } \\
\hline Altitude (m) & & Alt & 1283 & 1245 & 1351 & 1272 & 1271 & 1426 \\
\hline Slope $\left({ }^{\circ}\right)$ & & Slope & 21.05 & 0.61 & 0.91 & 0 & 8.4 & 11.95 \\
\hline \multirow{2}{*}{ Rock cover $(\%)$} & mean & $\mathrm{MRC}$ & 16.55 & 6.31 & 70.63 & 6.06 & 75.17 & 54.19 \\
\hline & $\mathrm{CV}$ & $\mathrm{RCCV}$ & 133.76 & 119.90 & 37.62 & 228.35 & 29.05 & 77.32 \\
\hline \multirow[t]{2}{*}{ Bare cover $(\%)$} & mean & $\mathrm{MBC}$ & 77.27 & 76.93 & 13.89 & 70.57 & 10.25 & 31.48 \\
\hline & $\mathrm{CV}$ & $\mathrm{BCCV}$ & 23.90 & 25.18 & 133.62 & 36.05 & 142.96 & 128.45 \\
\hline \multirow[t]{2}{*}{ Leaf litter cover $(\%)$} & mean & MLC & 0.08 & 1.38 & 8.06 & 19.16 & 6.76 & 4.68 \\
\hline & $\mathrm{CV}$ & $\mathrm{LCCV}$ & 29.33 & 180.20 & 170.17 & 133.93 & 167.54 & 162.91 \\
\hline \multicolumn{9}{|l|}{ Physiognomic variables } \\
\hline \multirow[t]{2}{*}{ Tree canopy (\%) } & mean & MTC & 0.12 & 8.29 & 16.66 & 30.37 & 18.84 & 15.44 \\
\hline & $\mathrm{CV}$ & TCCV & 30.13 & 196.06 & 156.48 & 124.45 & 135.32 & 139.81 \\
\hline \multirow[t]{2}{*}{ Vegetation at $1 \mathrm{~m}(\%)$} & mean & V1M & 0.12 & 7.63 & 15.23 & 18.57 & 17.0 & 14.06 \\
\hline & $\mathrm{CV}$ & $\mathrm{V} 1 \mathrm{CV}$ & 30.13 & 195.34 & 156.02 & 146.82 & 134.14 & 143.03 \\
\hline \multirow[t]{2}{*}{ Vegetation at $0.5 \mathrm{~m}(\%)$} & mean & V0.5M & 0.13 & 5.36 & 11.16 & 13.41 & 13.55 & 11.28 \\
\hline & $\mathrm{CV}$ & $\mathrm{V} 0.5 \mathrm{CV}$ & 48.16 & 183.81 & 162.28 & 157.07 & 143.32 & 139.10 \\
\hline
\end{tabular}


The most species-rich sites were mesquite woodlands, chical and columnar cactus slopes, with 36,35 and 33 species, respectively. Only four species occurred in barrens (see Appendix). Species-richness per sampling plot showed significant differences among sites (ANOVA test; $\mathrm{F}=56.375 ; \mathrm{df}=5 ; \mathrm{P}<0.001$ ). The a posteriori analysis revealed differences between barrens and saltbush with more species (15) in the latter, and among these two sites and all others. Chical also had a significantly larger number of species than creosote bush scrub (the latter had 23 species).

\section{Floristic composition}

The similarity index between pairs of sites showed generally low values. Sites can be ranked, with barrens at one extreme (mean similarity index $<0.02$ ) and larger values (i.e. > 0.58 ) in comparisons between columnar cactus slopes with chical and creosote bush scrub. Other comparisons gave index values intermediate between the above mentioned (Table 2). The analysis of similarity within each site also produced low values. The most heterogeneous site was chical (mean $\pm \mathrm{SD}$; $0.245 \pm 0.116)$, followed by mesquite woodlands $(0.276 \pm 0.108)$ and columnar cactus slopes $(0.284 \pm 0.124)$. Saltbush $(0.304 \pm 0.216)$ and creosote bush scrub $(0.347 \pm 0.149)$ were the most homogeneous.

The first two axes of the PCA relating to floristic composition, explained $58.45 \%$ of total variance (Fig. 2), indicating the existence of a dual floristic gradient and showed an initial segregation of sites. The MANOVA carried out on the first two axes of the PCA showed significant differences among sites (MANOVA test; $\mathrm{F}=22.464 ; \mathrm{df}=10 ; \mathrm{P}<0.001)$, confirming the detected pattern. The results of the a posteriori Tukey's test for axis 1 revealed significant differences only between mesquite woodlands and the remaining sites $(\mathrm{P}<0.001)$, separating the observations of the former from those of the others, with mesquite associated with $P$. chilensis, Larrea divaricata (Cav.), Atriplex lampa (Gill. ex Moq.), Grabowskia obtusa (Arn.), Senecio subulatus (Don ex Hook. \& Arn.) and Lycium chilense (Miers ex Bert.). The same test for axis 2 separated barrens, saltbush and mesquite woodlands from creosote bush scrub and columnar cactus slopes $(\mathrm{P}<0.001$, Fig. 3A), whereas chical shared characteristics with both groups. These tests showed that sites could not be differentiated purely on floristic criteria.

A second PCA on floristic composition, after omitting mesquite woodlands, yielded clearer results. The MANOVA performed on the first two axes of this second PCA (explained variance $=51.64 \%)$ once again showed significant differences between sites (MANOVA test; $\mathrm{F}=9.765 ; \mathrm{df}=8 ; \mathrm{P}<0.001$ ). Post hoc Tukey's test for the first axis differentiated barrens and saltbush from creosote bush scrub and columnar cactus slopes $(\mathrm{P}<0.001)$, whereas gradient 2 separated creosote bush scrub from the others $(\mathrm{P}<0.001)$. Barrens and saltbush still remained undifferentiated and as well as chical with the rest.

Kruskal-Wallis tests showed differences in plant species cover among sites $(\mathrm{P}<0.05$; see Appendix), confirming that some species were specific to sites, although overall communities were not clearly distinguishable with PCAs.

TABLE 2

Values of floral similarity (Jaccard index) between the sampled sites.

Valores de similitud floral (índice de Jaccard) entre las zonas de muestreo.

\begin{tabular}{|c|c|c|c|c|c|}
\hline & Columnar cactus slopes & Chical & Creosote bush scrub & Mesquite woodlands & Saltbush \\
\hline Barrens & 0.03 & 0.02 & 0.00 & 0.03 & 0.00 \\
\hline Saltbush & 0.23 & 0.20 & 0.18 & 0.21 & \\
\hline Mesquite woodlands & 0.30 & 0.31 & 0.30 & & \\
\hline Creosote bush scrub & 0.58 & 0.48 & & & \\
\hline Chical & 0.75 & & & & \\
\hline
\end{tabular}




\section{Vegetation structure and physiognomy}

The PCA performed on the structural and physiognomic variables of the vegetation proved to be as explanatory as the PCA of floristic composition. Axis 1 (explained variance $=30.9 \%$ was associated positively with $\mathrm{MBC}$ and negatively with MRC and BCCV (Table 3), discriminating observations of large expanses of bare ground from those of large extents of rocky cover and large heterogeneity of bare ground. Axis 2 of PCA (explained variance $=25.3 \%$ ) showed positive correlations with MTC, V1M, V0.5M and MLC, distinguishing the presence of sites with high plant and litter cover.
The MANOVA carried out on the first two axes of PCA showed significant differences between sites (MANOVA; $\mathrm{F}=42.992 ; \mathrm{df}=10 ; \mathrm{P}$ $<0.001)$. The a posteriori Tukey's test on axis 1 differentiated barrens from the other sites ( $P$ $<0.001)$, with very high values for bare ground (Table 1), whereas saltbush and mesquite woodlands were also segregated from the other sites. Columnar cactus slopes, creosote bush scrub and chical remained grouped together (Fig. 3B), due to high values for rocky cover and high variability of plant cover at different levels (Table 1). Axis 2 only segregated mesquite woodlands from the other sites, on the basis of the former's high canopy and litter cover (Fig. 3B).

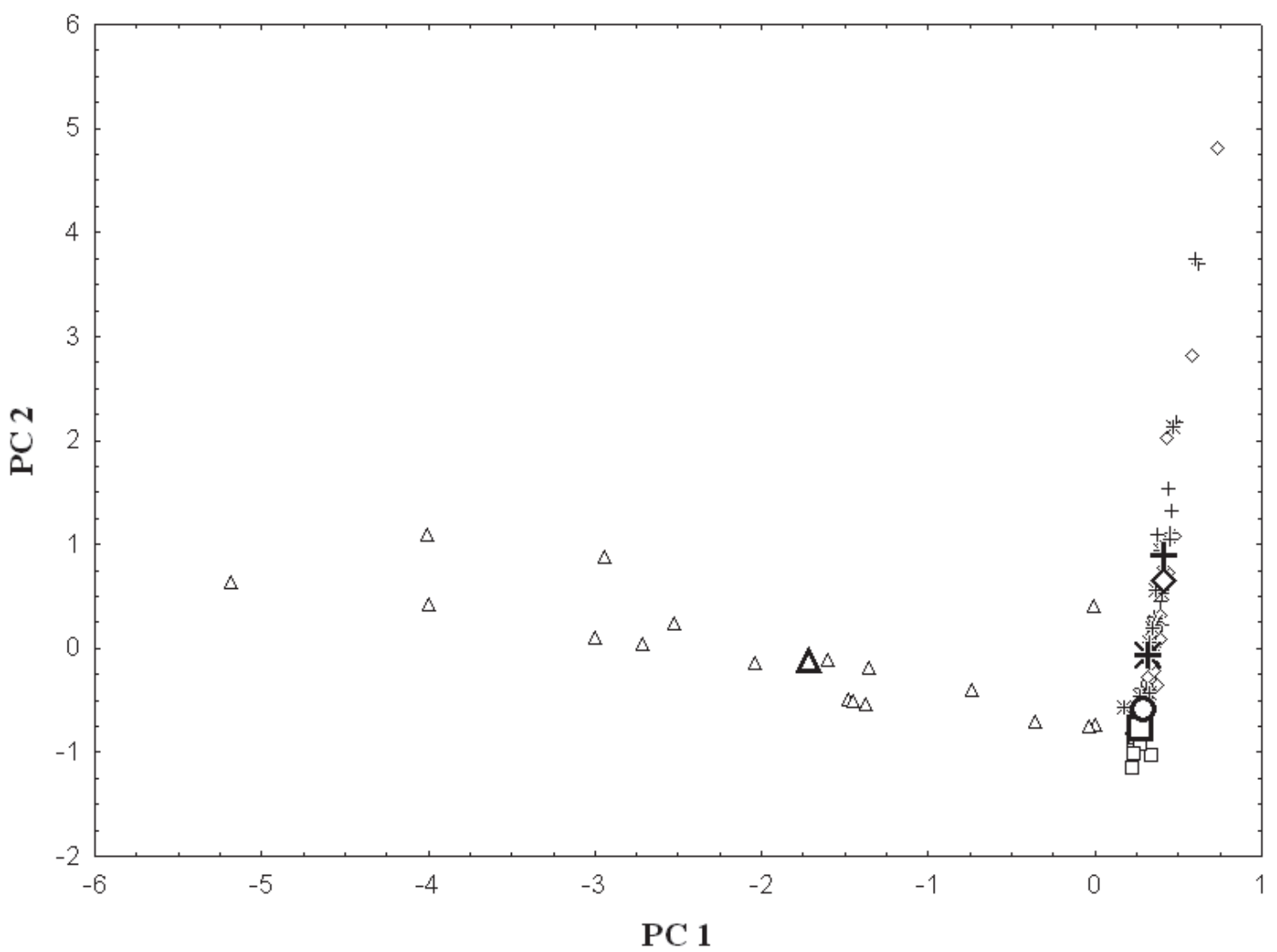

Fig. 2: Principal Component Analysis of observations of all species in the six sites. Component 1 separates observations of mesquite woodlands $(\Delta)$ and component 2 represents the gradient of the rest of observations. Barrens (o), saltbush $(\square)$, creosote bush scrub $(\diamond)$, columnar cactus slopes $(+)$ and chical $\left({ }^{\star}\right)$. Identical but larger symbols represent the centroids of observations of sites.

Análisis de Componentes Principales con las observaciones de todas las especies en las seis zonas. El componente 1 separa las observaciones del algarrobal $(\Delta)$ y el componente 2 representa el gradiente del resto de observaciones. Peladal (o), zampal $(\square)$, jarillal $(\diamond)$, laderas con cactus columnares $(+)$ y chical $\left(^{*}\right)$. Símbolos idénticos pero de mayor tamaño representan los centroides de las observaciones de las zonas. 

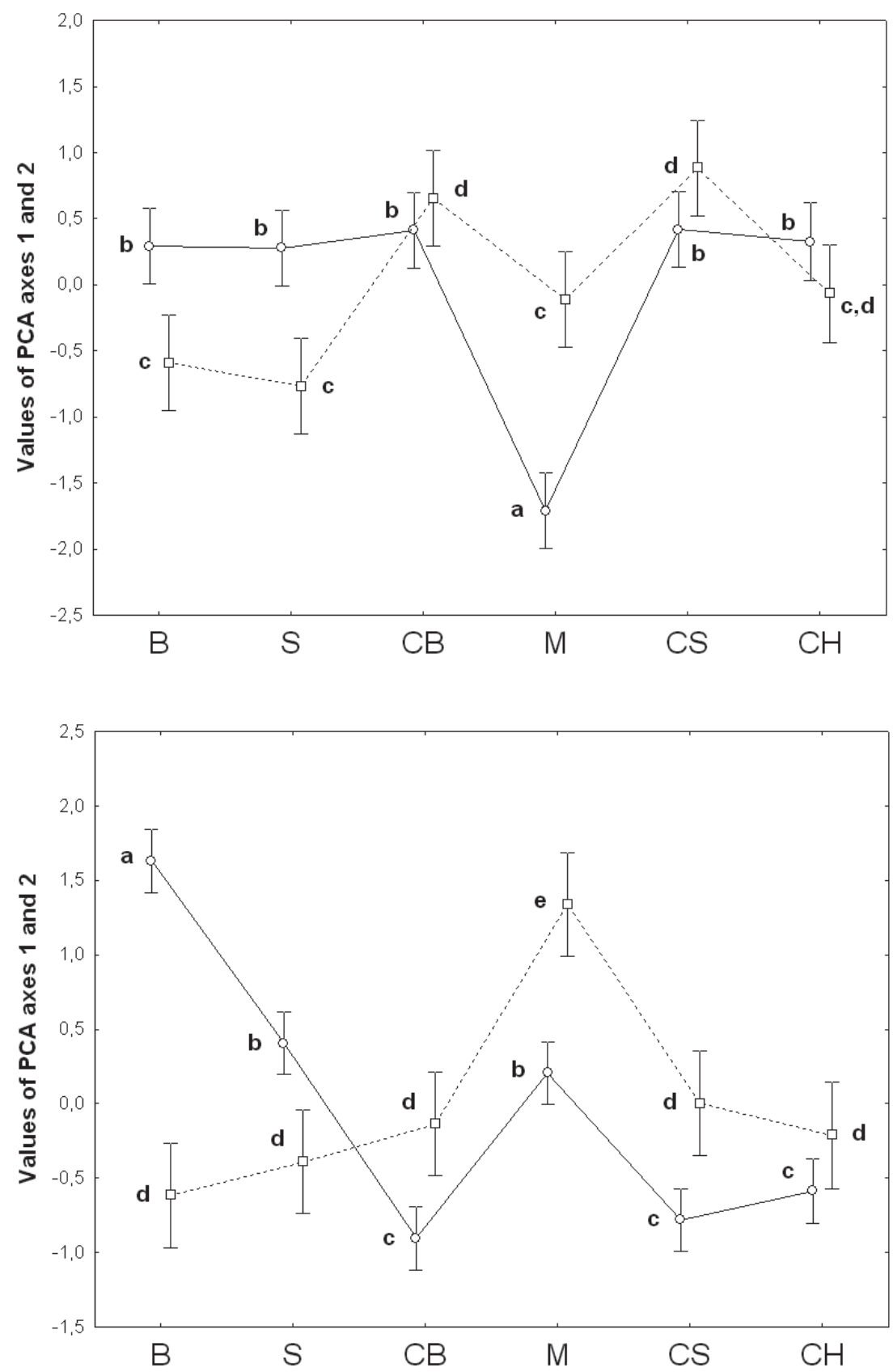

Fig. 3: Means and standard deviations for the two dependent variables in the MANOVA test for floristic composition (A) and environmental and vegetation-structure variables (B) at the six sites. In both diagrams the continuous line corresponds to gradient 1 and the broken line to gradient 2 derived from the PCA. Different letters for values of the same factor indicate significant differences $(\mathrm{P}<0.05)$ between sites. Barrens (B), Saltbush (S), creosote bush scrub (CB), mesquite woodlands (M), columnar cactus slopes (CS) and chical $(\mathrm{CH})$.

Medias y desviaciones estándar de las dos variables dependientes en el test de MANOVA de composición florística (A) y de las variables ambientales y de estructura de la vegetación (B) para las seis zonas. En ambos diagramas la línea continua corresponde al gradiente $1 \mathrm{y}$ la línea discontinua al gradiente 2 del ACP. Letras diferentes para valores del mismo factor indican diferencias significativas $(\mathrm{P}<0.05)$ entre zonas. Peladal $(\mathrm{B})$, zampal $(\mathrm{S})$, jarillal $(\mathrm{CB})$, algarrobal $(\mathrm{M})$, laderas con cactus columnares $(\mathrm{CS})$ y chical $(\mathrm{CH})$. 


\section{TABLE 3}

Results of the Principal Component Analyses carried out to synthesise the variation in environmental and structural characteristics at the sampling plots. Asterisks indicate the highest factor scores.

Resultados de los Análisis de Componentes Principales realizados para sintetizar la variabilidad en las características ambientales y estructurales en las parcelas de muestreo. Los asteriscos indican los valores más altos de los factores de puntuación.

\begin{tabular}{lcc}
\hline Variable & PC 1 & PC 2 \\
\hline Altitude & -0.408 & -0.131 \\
Slope & 0.353 & -0.294 \\
Mean tree canopy & -0.383 & $0.889^{*}$ \\
Tree canopy CV & -0.591 & -0.344 \\
Mean vegetation at 1 m & -0.504 & $0.801^{*}$ \\
Vegetation at 1 m CV & -0.584 & -0.277 \\
Mean vegetation at 0.5 m & -0.508 & $0.769^{*}$ \\
Vegetation at 0.5 m CV & -0.570 & -0.229 \\
Mean rock cover & $-0.727^{*}$ & -0.351 \\
Rock cover CV & 0.458 & 0.466 \\
Mean bare ground & $0.815^{*}$ & 0.188 \\
Bare ground CV & $-0.758^{*}$ & -0.257 \\
Mean leaf litter cover & -0.207 & $0.852^{*}$ \\
Leaf litter cover CV & -0.594 & -0.082 \\
Explained variation (\%) & 30.89 & 25.32 \\
\hline
\end{tabular}

\section{DISCUSSION}

Our data represent the first quantitative description of the structure and composition of plant communities of the hyper-arid Monte Desert, a largely unknown South American temperate desert. They indicate a gradient of communities with a high level of intrinsic heterogeneity due to presence of many shared species with fairly well-defined extremes.

Characteristics of the plant communities of this part of Monte Desert are similar to those of other deserts (Orians \& Solbrig 1977, Abd ElGhani 2000). The vegetation is typically xerophytic, low in cover, and greatly heterogeneous in floristic composition. The clear dominance of woody species vs. herbs is possibly due to the ability of extensive root systems to exploit water at different soil depths (Abd El-Ghani 2000). In contrast, herbaceous plants, which are much more dependent on seasonal rain (Vidiella et al. 1999), were sparsely represented, despite sampling having accounted at the end of the rainy season.

With respect to differentiation, the analyses of floristic composition showed the difficulty of segregating distinct communities, due to high levels of internal heterogeneity and overlap between the different sites. Floristic composition is clearly distinct at extremes of the moisture gradient with mesquite woodlands along margins of dry watercourses, which occasionally have water after heavy rains. They include species which are linked to water presence such as $P$. chilensis, Baccharis salicifolia (Ruiz \& Pav. Pers.), Tessaria dodoneaefolia (Hook. et Arn.) or Schinus polygamus (Cav.).

Ordination on structural variables helps shape this pattern, segregating communities on the basis of substrate type, and tree and shrub cover. Canopy cover segregated mesquite woodlands from the other communities, which indicates the high structural and physiognomic similarity of most plant communities in the Monte Desert. Furthermore, the multivariate analyses segregate sites situated on sandy or silty substrata (mesquite woodlands, saltbush and barren) from those on rocky and more heterogeneous substrata. Saltbush, dominated by zampa (A. spegazzinii), along with halophytic species such as Suaeda divaricata (Moq.), Plectrocarpa tetracantha (Gill. ex Hook.) or Prosopis strombulifera (Benth) occurred in communities on sandy-silty soils. This community is scattered and near dry riverbeds, and unlike other deserts, where saltbush communities were most often found on harder, stony soils (Fernandez-Gimenez \& Allen-Diaz 2001), in the Monte Desert they associated with sandy and disaggregated soils. Barren areas occur in zones well away from influence of phreatic level. Surface is often eroded and of irregular topography; this impedes vegetation presence except at drainage points (Orians \& Solbrig 1977). Only a few halophytic Crassulaceae, such as Sclerophylax kurtzii (Di Fulvio) and Halophytum ameghinoi (Speg.), grow there, being well-adapted to aridity and salinity.

The above-mentioned findings are consistent with deterministic models of vegetation distribution in arid regions, in which water availability is the essential factor 
in the structuring and functionality of distinguishable plant communities (Noy-Meir 1973, Jobbágy et al. 1996, León de la Luz et al. 2000, Zhang et al. 2005). As has been suggested for other desert zones, patchiness in soil types together with distance from water are the two principal factors which contribute to shaping the distribution of plant communities in deserts (Beyer et al. 1998, Fernandez-Gimenez \& Allen-Diaz 2001), as a result of the redistribution of water, soil particles, propagules, and resources which create and maintain vegetation patches (Aguiar \& Sala 1999). In Monte Desert, plant communities differentiated on the basis of floristic and physiognomic variables seem to result from the existence of a dual gradient edaphic factors and distance from watercourses- producing significant differences in floristic composition as either one of them varies, as proposed in Fig. 4.

The differentiation which we have shown should be considered within the context of a continuum of variation between plant communities, however. The floristic similarity data show a high number of species in common between creosote bush scrub, columnar cactus slopes and chical. Under the most usual conditions within the region, on harder, coarser and more heterogeneous soils,

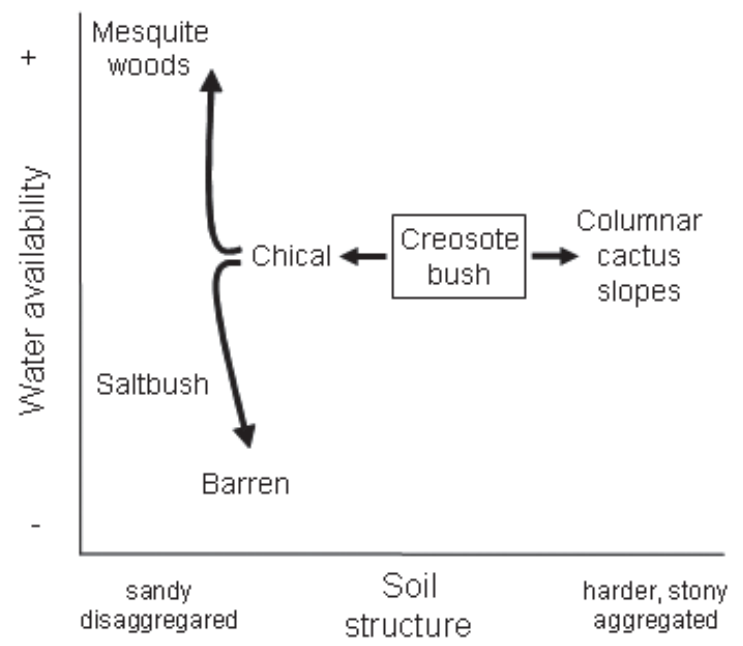

Fig. 4: Conceptual diagram of the relationships of vegetation with soil structure and water availability in the Monte Desert.

Esquema conceptual de las relaciones de las comunidades vegetales en función de la estructura del suelo y de la disponibilidad hídrica en el Desierto del Monte. the predominant community of the hyper-arid Monte Desert is creosote bush scrub, which is principally characterized by the abundance of L. cuneifolia and $Z$. punctata. Creosote bush scrub shows small floristic differences when it is situated directly on bare rock, allowing the inclusion of physiognomically-prominent elements such as cacti and bromeliads including Trichocereus strigosus (Salm-Dyck), Echinopsis leucantha (Walp), Opuntia sulphurea (G. Don ex Loudon) or Tephrocactus spp., and especially Deuterocohnia longipetala (Mez) and T. terscheckii, although not so frequent to allow floristic differentiation of these sites. Differentiated sites such as columnar cactus slopes do not seem to be limited by water availability due to irregular topography and frequent fissures which retain some humidity and permit $R$. girolae on rocky substrates in some zones. The very low values of the intralocality similarity index in chical and columnar cactus slopes confirm this impression, pointing to the high degree of spatial heterogeneity which seems to be associated with a structuring of vegetation in bands dependent on watercourses (Aguiar \& Sala 1999).

Unlike this small scale heterogeneity of lithological origin, creosote bush scrub and saltbush show higher intralocality similarity values. These communities are situated in flat areas where rainwater spreads more evenly and vegetation is more uniformly distributed. Vegetation here is structured in a leopard-spot pattern, where wind and animals are the principal factors responsible for its distribution (Aguiar \& Sala 1999). Here, presence of scrub favours structuring in relatively dense patches, where spatial aggregation by facilitation phenomena are produced (Tirado \& Pugnaire 2003).

The results of the species-richness analysis help to reinforce the patterns detected in the analyses of floristic composition and structural and physiognomic variables. The two communities at the extremities of the dryness gradient, saltbush and barren, had the lowest species diversity, confirming that species richness in arid areas increases with water availability (Cornwell \& Grubb 2003), parallel to productivity (Waide et al. 1999). The greater plant cover in the columnar cactus slopes, mesquite woodlands and chical communities 
produces a concentration of water and nutrients beneath their canopies as well as shielding from intense solar radiation (Rossi \& Villagra 2003), and results in an overall increase in productivity and diversity in arid zones (Sala \& Aguiar 1996, Tirado \& Pugnaire 2003).

Finally, like vegetation in Monte Desert is mainly organized in gradients, not being easy to define plant communities sensu stricto, conservation targets should focus on increasing surface of protected areas in order to guarantee all the heterogeneity.

\section{ACKNOWLEDGEMENTS}

This study has been supported by the BBVA Foundation through the INTERMARG project under its Program for Conservation Biology Projects. We wish to thank the administration and all the staff of the Ischigualasto Provincial Park for their cooperation and help, as well as three anonymous referees for comments on earlier versions of this manuscript. M. Almirón helped in plant identification and R. Ovejero in field work. Partial support for UAM researchers is provided by the REMEDINAL-2 research network (S2009/AMB/1783).

\section{LITERATURE CITED}

ABD EL-GHANI MM (2000) Floristics and environmental relations in two extreme desert zones of western Egypt. Global Ecology and Biogeography 9: 499-516.

ABD EL-GHANI MM \& WM AMER (2003) Soilvegetation relationships in a coastal desert plain of southern Sinai, Egypt. Journal of Arid Environments 55: 607-628.

AGUIAR MR \& OE SALA (1999) Patch structure, dynamics and implications for the functioning of arid ecosystems. Trends in Ecology and Evolution 14: 273-277.

BERTILLER MB, L MARONE, R BALDI \& JO ARES (2009) Biological interactions at different spatial scales in the Monte desert of Argentina. Journal of Arid Environments 73: 212-221.

BEYER L, K TIELBÖRGER, H-P BLUME, U PFISTERER, K PINGPANK \& D PODLECH (1998) Geo-ecological soil features and the vegetation pattern in an arid dune area in the Northern Negev, Israel. Zeitschrift für Pflanzenernährung und Bodenkunde (Germany) 161: 347-356.

BISIGATO AJ, PE VILLAGRA, JO ARES \& BE ROSSI (2009) Vegetation heterogeneity in Monte Desert ecosystems: A multi-scale approach linking patterns and processes. Journal of Arid Environments 73: 182-191.

CABRERA AL (1994) Regiones fitogeográficas argentinas. Enciclopedia argentina de agricultura y jardinería. Tomo II. Fascículo I. Editorial ACME S.A.C.I. Buenos Aires.

CAMPOS C, SM GIANNONI, P TARABORELLI \& CE
BORGHI (2007) Removal of mesquite seeds by small rodents in the Monte desert, Argentina. Journal of Arid Environments 69: 228-236.

CORNWELL WK \& PJ GRUBB (2003) Regional and local patterns in plant species richness with respect to resource availability. Oikos 100: 417428.

DALMASSO A \& J MÁRQUEZ (1999) Vegetación actual de San Juan. In: Paredes JD, GM Suvires \& JV Zambrano (eds) Síntesis del Cuaternario de la Provincia de San Juan, Argentina. CD-ROM Edition. San Juan.

DEBANDI G, B ROSSI, J ARANÍBAR, JA AMBROSETTI \& IE PERALTA (2002) Breeding system of Bulnesia retamo (Gillies ex Hook \& Arn.) Gris. (Zygophyllaceae) in the Central Monte Desert (Mendoza, Argentina). Journal of Arid Environments 5: 141-152.

FERNANDEZ-GIMENEZ M \& B ALLEN-DIAZ (2001) Vegetation change along gradients from water sources in three grazed Mongolian ecosystems. Plant Ecology 157: 101-118.

GARCÍA LV (2004) Escaping the Bonferroni iron claw in ecological studies. Oikos 105: 657-663.

IPNI (2004) The International Plant Names Index. URL: http://www.ipni.org/ (accessed June 1, 2010).

JOBBÁGY EG, JM PARUELO \& RJC LEÓN (1996) Vegetation heterogeneity and diversity in flat and mountain landscapes of Patagonia. Journal of Vegetation Science 7: 599-605.

LEÓN DE LA LUZ JL, JJ PÉREZ-NAVARRO \& A PRECEDA (2000) A transitional xerophitic tropical plant community of the Cape Region, Baja California. Journal of Vegetation Science 11: 555-564.

LÓPEZ DE CASENAVE J, VR CUETO \& L MARONE (1998) Granivory in the Monte desert: Is it less intense than in other arid zones of the world? Global Ecology and Biogeography Letters 7: 197204.

MARONE L, ME HORNO \& R GONZÁLEZ DEL SOLAR (2000) Post-dispersal fate of seeds in the Monte desert of Argentina: Patterns of germination in successive wet and dry years. Journal of Ecology 88: 940-949.

MÁRQUEZ J, E MARTÍNEZ-CARRETERO, A DALMASSO, G PASTRÁN \& S ORTIZ (2005) Las áreas protegidas de la provincia de San Juan II. La vegetación del Parque Provincial Ischigualasto. Multequina (Argentina) 14: 1-27.

MILENNIUM ECOSYSTEM ASSESSMENT (2005) Ecosystems and Human Well-Being: Synthesis. Island Pres, Washinton DC, USA.

MORELLO JH (1958) La provincia fitogeográfica de Monte. Opera Lilloana II. Tucumán. Argentina.

NOY-MEIR I (1973) Desert ecosystems: Environments and producers. Annual Review of Ecology and Systematics 4: 25-51.

ORIANS GH \& OT SOLBRIG (1977) Convergent evolution in warm deserts. US/Synthesis series, 3. Dowden, Hutchinson \& Ross, Inc. Pensylvania.

POBLETE AG \& JL MINETTI (1999) Atlas climatológico de San Juan. Instituto de Geografía Aplicada, UNSJ. CD-ROM Edition. INGEO, San Juan.

POL RG, SR CAMÍN \& AA ASTIÉ (2006) La situación ambiental de la ecorregión del Monte. In: Brown A, U Martínez-Ortiz, M Acerbi \& J Corcuera 
(eds) La situación ambiental argentina: 227-239. Fundación Vida Silvestre Argentina.

QUINN GP \& MJ KEOUGH (2002) Experimental design and data analysis for biologists. Cambridge University Press.

ROIG FA (1960) Bosquejo fitogeográfico de las provincias de Cuyo. Publicación No 3. Facultad de Ciencia Agrarias. U.N.C. CAPERAS. Subcomité Zona Cuyo.

ROIG FA, S ROIG-JUÑENT \& V CORBALÁN (2009) Biogeography of the Monte Desert. Journal of Arid Environments 73: 164-172.

ROSSI BE, GO DEBANDI, IE PERALTA \& E MARTÍNEZ-PALLE (1999) Comparative phenology and floral patterns in Larrea species (Zygophyllaceae) in the Monte desert (Mendoza, Argentina). Journal of Arid Environments 43: 213-226.

ROSSI BE \& PE VILLAGRA (2003) Effects of Prosopis flexuosa on soil properties and the spatial pattern of understorey species in arid Argentina. Journal of Vegetation Science 14: 543-550.

SALA OE \& MR AGUIAR (1996) Origin, maintenance, and ecosystem effect of vegetation patches in arid lands. In: West $\mathrm{N}$ (ed) Rangelands in a sustainable biosphere: 29-32. Proceedings of the Fifth International Rangeland Congress Vol. 2, Society for Range Management, Denver.
STATSOFT, INC (2007) STATISTICA (data analysis software system), version 8.0.

TIRADO R \& FI PUGNAIRE (2003) Shrub spatial aggregation and consequences for reproductive success. Oecologia 136: 296-301.

VIDIELLA PE, JJ ARMESTO \& JR GUTIÉRREZ (1999) Vegetation changes and sequential flowering after rain in the southern Atacama desert. Journal of Arid Environments 43: 449-458.

VILLAGRA PE \& JB CAVAGNARO (2006) Water stress effects on the seedling growth of Prosopis argentina and Prosopis alpataco. Journal of Arid Environments 64: 390-400.

WAIDE RB, MR WILLIG, CF STEINER, G MITTELBACH, L GOUGH, SI DODSON, GP JUDAY \& R PARMENTER (1999) The relationship between productivity and species richness. Annual Review of Ecology and Systematics 30: 257-300.

XU L, H LIUA, X CHUC \& K SUA (2006) Desert vegetation patterns at the northern foot of Tianshan Mountains: The role of soil conditions. Flora 201: 44-50.

ZHANG YM, YN CHEN \& BR PAN (2005) Distribution and floristics of desert plant communities in the lower reaches of Tarim River southern Xinjiang, People's Republic of China. Journal of Arid Environments 63: 772-784. 


\section{APPENDIX}

Percentage cover (mean \pm SD) of all species in the six sampling sites. Plant cover species with differences among sites $(\mathrm{P}<0.05$; Kruskal-Wallis test, corrected by FDR rule) are indicated with asterisk. $\mathrm{N}=20$ sampling plots each with 13 subplots in all cases (IPNI 2004).

Porcentaje de cobertura (media $\pm \mathrm{DE}$ ) de todas las especies en las seis zonas de muestreo. Las plantas con diferencias en las coberturas entre zonas $(\mathrm{P}<0.05$; test Kruskal-Wallis, corregido por la regla FDR) se muestran con asterisco. $\mathrm{N}=20$ parcelas de muestreo cada una con 13 sub-parcelas en todos los casos (IPNI 2004).

\begin{tabular}{|c|c|c|c|c|c|c|}
\hline Species list & Barrens & Saltbush & $\begin{array}{l}\text { Creosote } \\
\text { bush scrub }\end{array}$ & $\begin{array}{c}\text { Mesquite } \\
\text { woodlands }\end{array}$ & $\begin{array}{l}\text { Columnar } \\
\text { cactus slopes }\end{array}$ & Chical \\
\hline Aristida mendocina ${ }^{*}$ & - & - & $0.02 \pm 0.04$ & $1.60 \pm 3.70$ & - & - \\
\hline Atriplex lampa* & - & $0.12 \pm 0.52$ & - & $0.45 \pm 0.80$ & - & - \\
\hline Atriplex litophila* & - & - & - & - & - & $0.43 \pm 0.86$ \\
\hline Atriplex spegazzinii* & - & $3.92 \pm 4.05$ & - & $1.98 \pm 1.92$ & $0.15 \pm 0.54$ & $0.89 \pm 1.94$ \\
\hline Baccharis salicifolia ${ }^{*}$ & - & - & - & $1.55 \pm 3.49$ & - & $0.33 \pm 1.43$ \\
\hline Bulnesia retamo* & - & $1.37 \pm 2.48$ & $2.36 \pm 3.26$ & $0.42 \pm 1.56$ & $0.51 \pm 1.36$ & - \\
\hline Capparis atamisquea ${ }^{*}$ & - & - & $0.40 \pm 1.42$ & $1.66 \pm 2.95$ & $0.25 \pm 0.77$ & $0.02 \pm 0.06$ \\
\hline Cercidium praecox & - & - & $0.08 \pm 0.34$ & $0.72 \pm 1.83$ & $0.27 \pm 0.73$ & $0.11 \pm 0.36$ \\
\hline Cereus aethiops & - & - & $0.00 \pm 0.02$ & - & - & - \\
\hline Clematis montevidensis & - & - & - & $0.00 \pm 0.02$ & - & - \\
\hline Cyclolepis genistoides & - & - & $0.08 \pm 0.34$ & $0.07 \pm 0.26$ & $0.03 \pm 0.14$ & $0.12 \pm 0.39$ \\
\hline Denmoza rhodacantha* & - & - & - & - & $0.08 \pm 0.20$ & $0.06 \pm 0.16$ \\
\hline Deuterocohnia longipetala* & - & - & - & - & $1.70 \pm 2.58$ & - \\
\hline Digitaria californica * & - & - & - & - & $0.02 \pm 0.06$ & - \\
\hline Distichlis spicata & - & - & - & $0.03 \pm 0.09$ & - & - \\
\hline Ditaxis malpighipila & - & - & - & - & - & $0.01 \pm 0.04$ \\
\hline Echinopsis leucantha * & - & - & $0.05 \pm 0.17$ & - & $0.13 \pm 0.16$ & $0.02 \pm 0.06$ \\
\hline Geoffroea decorticans & $0.10 \pm 0.43$ & - & - & $0.55 \pm 1.50$ & $0.35 \pm 1.07$ & $0.04 \pm 0.11$ \\
\hline Gomphrena pulchella & - & - & - & $0.00 \pm 0.02$ & - & - \\
\hline Grabowskia obtuse * & - & - & - & $0.08 \pm 0.24$ & - & - \\
\hline Grahamia bracteata & - & - & - & $0.00 \pm 0.02$ & - & - \\
\hline \multicolumn{7}{|l|}{ Gymnocalycium } \\
\hline bodenbenderianum * & - & - & - & - & $0.03 \pm 0.09$ & - \\
\hline \multicolumn{7}{|l|}{ Gymnocalycium } \\
\hline schickendantzii & - & - & $0.00 \pm 0.02$ & - & $0.01 \pm 0.04$ & - \\
\hline Halophytum ameghinoi & $0.00 \pm 0.02$ & - & - & - & - & - \\
\hline Heterostachys ritteriana ${ }^{*}$ & - & - & - & - & - & $0.09 \pm 0.27$ \\
\hline Hoffmanseggia sp. & - & - & - & $0.01 \pm 0.02$ & - & - \\
\hline Larrea cuneifolia * & - & $0.00 \pm 0.02$ & $5.17 \pm 5.11$ & $0.46 \pm 1.53$ & $3.24 \pm 3.63$ & $1.15 \pm 2.54$ \\
\hline Larrea divaricata ${ }^{*}$ & - & $0.10 \pm 0.35$ & - & $6.40 \pm 6.21$ & $0.13 \pm 0.53$ & $0.29 \pm 0.70$ \\
\hline Lippia integrifolia & - & - & - & $0.52 \pm 1.09$ & - & - \\
\hline Lycium chilense $e^{*}$ & - & $0.00 \pm 0.02$ & - & $0.15 \pm 0.44$ & - & - \\
\hline Lycium ciliatum & - & - & - & - & - & - \\
\hline
\end{tabular}




\begin{tabular}{|c|c|c|c|c|c|c|}
\hline Species list & Barrens & Saltbush & $\begin{array}{l}\text { Creosote } \\
\text { bush scrub }\end{array}$ & $\begin{array}{c}\text { Mesquite } \\
\text { woodlands }\end{array}$ & $\begin{array}{l}\text { Columnar } \\
\text { cactus slopes }\end{array}$ & Chical \\
\hline Lycium tenuispinosum * & - & $0.02 \pm 0.09$ & $0.01 \pm 0.05$ & $0.17 \pm 0.41$ & $0.04 \pm 0.12$ & $0.41 \pm 0.72$ \\
\hline Maytenus viscifolia * & - & - & $0.13 \pm 0.42$ & - & $0.83 \pm ’ 2.56$ & - \\
\hline Mimosa ephedroides* & - & - & $0.04 \pm 0.17$ & $0.00 \pm 0.02$ & $0.08 \pm 0.27$ & $0.98 \pm 1.62$ \\
\hline Monttea aphyla * & - & - & - & - & $0.44 \pm 1.18$ & $0.48 \pm 0.90$ \\
\hline Opuntia sulphurea * & - & - & $0.13 \pm 0.37$ & $0.00 \pm 0.02$ & $0.28 \pm 0.47$ & $0.81 \pm 0.87$ \\
\hline Pappophorum sp. * & - & - & - & - & - & $0.06 \pm 0.16$ \\
\hline Philibertia gilliesii & - & - & - & - & - & $0.00 \pm 0.02$ \\
\hline Plectrocarpa tetracantha* & - & $2.16 \pm 3.96$ & $0.55 \pm 1.69$ & $0.32 \pm 1.17$ & $0.10 \pm 0.26$ & $0.05 \pm 0.18$ \\
\hline Prosopis chilensis ${ }^{*}$ & - & - & - & $14.4 \pm 12.9$ & - & - \\
\hline Prosopis flexuosa* & - & $0.22 \pm 0.68$ & - & $1.29 \pm 3.42$ & - & $0.39 \pm 1.18$ \\
\hline Prosopis strombulifera * & - & $0.34 \pm 1.04$ & - & - & - & - \\
\hline Prosopis torquata ${ }^{*}$ & - & $0.15 \pm 0.69$ & $2.84 \pm 4.29$ & - & $4.22 \pm 3.90$ & $0.95 \pm 1.40$ \\
\hline Ramorinoa girolae & - & - & - & - & - & $1.88 \pm 3.83$ \\
\hline Salvia gilliesii & $0.01 \pm 0.05$ & - & - & - & - & - \\
\hline Schinus polygama & - & - & - & $0.33 \pm 1.01$ & - & - \\
\hline Sclerophylax kurtzii & $0.00 \pm 0.02$ & - & - & - & - & - \\
\hline Senecio riojanus & - & - & - & - & - & $0.06 \pm 0.19$ \\
\hline Senecio subulatus* & - & - & - & $0.77 \pm 1.90$ & - & - \\
\hline Senna aphyla* & - & $0.08 \pm 0.34$ & $0.62 \pm 1.52$ & - & $0.37 \pm 1.15$ & $0.62 \pm 1.18$ \\
\hline Sporobolus rigens & - & $0.03 \pm 0.15$ & - & - & - & - \\
\hline Suaeda divaricata ${ }^{*}$ & - & $0.87 \pm 1.69$ & - & $1.11 \pm 1.62$ & $0.03 \pm 0.09$ & $0.60 \pm 1.17$ \\
\hline Tephrocactus alexanderi ${ }^{*}$ & - & - & $0.07 \pm 0.26$ & - & $0.95 \pm 1.47$ & $0.15 \pm 0.37$ \\
\hline Tephrocactus aoracanthus* & - & - & $0.28 \pm 0.52$ & $0.00 \pm 0.02$ & - & $0.13 \pm 0.33$ \\
\hline \multicolumn{7}{|l|}{ Tephrocactus articulatus var. } \\
\hline oligacanthus* & - & - & - & $0.04 \pm 0.08$ & - & - \\
\hline Tephrocactus halophilus* & - & - & $0.55 \pm 0.90$ & - & $0.04 \pm 0.19$ & - \\
\hline Tessaria absinthioides & - & $0.08 \pm 0.34$ & - & - & - & - \\
\hline Tessaria dodoneifolia * & - & - & - & $0.68 \pm 1.64$ & - & - \\
\hline Tillandsia aizoides* & - & - & $0.05 \pm 0.06$ & $0.00 \pm 0.02$ & $0.02 \pm 0.03$ & $0.01 \pm 0.02$ \\
\hline Tillandsia bryoides* & - & - & $0.27 \pm 0.33$ & - & $0.03 \pm 0.05$ & $0.04 \pm 0.09$ \\
\hline Tillandsia xiphioides* & - & - & $0.00 \pm 0.02$ & - & $0.00 \pm 0.02$ & $0.20 \pm 0.24$ \\
\hline Trichloris crinita & - & - & - & - & $0.00 \pm 0.02$ & - \\
\hline Trichocereus strigosus* & - & - & - & - & $0.22 \pm 0.39$ & $0.55 \pm 0.68$ \\
\hline Trichocereus terscheckii & - & - & - & - & $0.06 \pm 0.19$ & - \\
\hline Tricomaria usillo & - & - & $0.16 \pm 0.39$ & $0.10 \pm 0.43$ & $0.19 \pm 0.86$ & $0.01 \pm 0.05$ \\
\hline Tricycla spinosa ${ }^{*}$ & - & - & - & - & - & $0.37 \pm 0.66$ \\
\hline Tweedia brunonis & - & - & - & $0.08 \pm 0.34$ & - & - \\
\hline Wedelia glauca * & - & - & - & $0.01 \pm 0.03$ & - & - \\
\hline Zuccagnia punctata ${ }^{*}$ & - & - & $3.04 \pm 4.37$ & $0.60 \pm 1.84$ & $4.56 \pm 6.34$ & $2.33 \pm 3.94$ \\
\hline
\end{tabular}


